JOURNAL OF SECURITY AND SUSTAINABILITY ISSUES

ISSN 2029-7017 print/ISSN 2029-7025 online

2020 March Volume 9 Number 3

https://doi.org/10.9770/jssi.2020.9.3(7)

Scopus

\title{
THE COMBINED EFFECT OF RISK PERCEPTION AND RISK TOLERANCE ON THE INVESTMENT DECISION MAKING
}

\author{
Natnaporn Aeknarajindawat \\ Graduate School, Suan Sunandha Rajabhat University, Bangkok, Thailand \\ E-mail:natnaporn.ae@ssru.ac.th
}

Received 27 February 2019; accepted 10 January 2020; published 30 March 2020

\begin{abstract}
The increase in the investment complications in the current environment has increase the need of the good quality financial advices services. Based on this, the aim of the study is being to investigate the join effect of risk tolerance (RT) and risk perception (RP) on the individual risky asset allocation decision along with the other essential variable in the context of financial advice which is consist of financial literacy and trust. For this purpose, data was collected from the 210 financial advisors of the banking sectors by using a convenient sampling technique which yield a 70\% response rate. For analysis, Structural Equation Modeling (SEM) technique was employed. The SEM analysis has shown that trust has positive and significant association with the RP and FL, and FL also has a positive and significant association with the risk tolerance and while insignificant with the RP. In addition, RP and RT also have a positive and significant association with the asset allocation in the banking sector of Indonesia. Based on the findings, current study added a body of literature in the empirical findings which could become a new of area of research in future. The research limitations and future directions are also discussed at the end of the study.
\end{abstract}

Keywords: asset allocation, trust; risk tolerance; financial literacy; risk perception; banking sector; Indonesia

Reference to this paper should be made as follows: Aeknarajindawat, N. 2020. The combined effect of risk perception and risk tolerance on the investment decision making. Journal of Security and Sustainability Issues, 9(3), 807-818. https://doi.org/10.9770/jssi.2020.9.3(7)

JEL Classification: G1

\section{Introduction}

In the contemporary environment, with increasing individual wealth within the middle-and upper level earnings, it is necessary for the new investors to make a proper and significant decisions about the investment. For instance, there ae maximum investments decisions which are connected along with some of the risk stages, therefore it is very essential that investments could remain compatible in the risk profiles. The reason is that the risk describing is a complex and also time-consuming, therefore for enhancing the number of the investors are turn-off to financial advisors on the behalf of assistance. Therefore, Angelini, Radivoyevitch, McCrae, and Khorana (2019) contended that recent risk assessments (RM) procedures were employed through the financial advisors for measuring the client attitude and also for risk which could remain informal as well as their validity is still arguable. Furthermore, in practice, there are various evidence is suggesting that, the advisers just pay a lot of attention on financial risk tolerance (FRT). Consequently, they are to be a probably is overlook the clients risk perception (CRP) (Wang, Keller, \& Siegrist, 2011; Nasr, Alaei, Bakhshi, Rasoulyan, Tayaran, Farahi, 2019). Therefore, the unexperienced investors have been found observe a risk contrary from the financial advisers in the organizations (Costa Jr, McCrae, \& Löckenhoff, 2019; Diacon, Theron, Schuurmans, Van de Wal, \& Bolliger, 2004). So, this discrepancy among the risk perception of the financial advisers and also their clients could obtain a failure result in the RM process of the organizations. 
Grable (2008) described that FRT is considered to be an extreme quantity of uncertainty when someone is willing towards acceptance when financial decision is make. Additionally, in the personal and customer finance this definition has been used on extensively basis in the extant literature Grable (2008). According to this research FRP is defined in the way of the investors "beliefs, judgments, attitudes and approaches" for risk attributes in the investment product which is adapted from then study of that is based on the conceptualization of risk perception (RP). However, prior research is generally used on the separate influence of individual risk that is make on the decision-making without any combining effect. Nguyen, Gallery, and Newton (2016) also investigated the impact of the risk tolerance (RT) on each decision-making of the investment in the context of financial advice. While their study existing in the same context but they just pay attention on the association within the investment decisions and RT without any examining the significant character of the RP.

In the recent time, there are many evidences which are signifying an important association within the RP and RT after the "Global Financial Crisis" (GFC) in the world (Gibson, Michayluk, \& Van de Venter, 2013). These studies pay more attention on the influence of the GFC on perception as well as investor's RT in their place of clarifying in what way they operated and influenced on the risky decisions. Moved through a significant way but still there is an under-researched association among RP, RT, and investor management Nguyen et al.'s (2016) in the developing economies especially on the banking sector of Indonesia. As, this sector has a major social and economic development contribution in the Indonesia. Thus seeking this gap, the aim of the study is to examine, how could FRP affected the association among each investment decision-making and risk tolerance in the context of financial advice?

The current study was divided into the subsequent sections, "introduction, literature review, research methodology, analysis and discussions, conclusion, limitation and future direction of the study".

\section{Literature review and hypothesis development}

\subsection{Financial risk perception (FRP)}

It is indicated that early stage of research had found theory of decision making variables like probabilities (results (gain or loss outcomes), and volatilities (volatility of returns) are the basic factor that influence on the financial risk perception (FR) (de Goeij, Van Campenhout, \& Subotic, 2018; Koonce, McAnally, \& Mercer, 2015; Mellers \& Chang, 1994). On the other hand, as research advanced, studies are activated to searching evidence of the behavioral effects and, consequently, argued this type variable of decisiontheory alone are not entirely explaining how the individuals FRP are perceive (Sachse, Jungermann, \& Belting, 2012). By delivering more affluent theories, current studies engaged both kinds of the variables as of these dual theoretical perception in risk perception studies (Huber, Palan, \& Zeisberger, 2019; Sachse et al., 2012; Wang et al., 2011; Yin, Chen, \& Xiao, 2019). In addition Koonce et al. (2015) also found that mixture of two kinds of risk variables are well explained FRP. Table 1 remain summarizes the decisiontheory FRP and also behavioral variables.

\subsection{The relationship risk tolerance, risk perception and asset allocation}

The current study is extending the framework of Nguyen et al. (2016) through introducing of risk perception (RP) by the way of an intervening within risk tolerance (RT) and asset allocation. Framework of dual effects of the RT, RP as well as asset allocation clarified in the following Figure one. Previous studies in the social networks context has establish the supporting proof for the positive and significant influence of strong-tied and the trusting association on affectFNIAive acquisition of knowledge in the organizations (Bollen \& Posavac, 2018; Levin \& Cross, 2004; McCarthy \& Levin, 2019). In addition, the interrelationships within the trust and financial literacy (FL) in the framework is confirmed by the following study of (Tsai \& Hsu, 2019; Tsai, 2000) and (Erdemlioglu \& Joliet, 2019; Levin \& Cross, 2004). In the spite of being research conducted in various contexts, these both studies are found very important positive relation among the relational as well as structural features of knowledge transfer and association, advocat- 
ing that association features among parties that could support to promote the knowledge transfer (Ahmad, 2019). According to our investigation, adapted from the study of Dyer and Chu (2000) who explained the relationship and the structural features that could refers the extent of time that consumer is used in service of the financial advice. Trust in place of the relational structures that mentions towards willingness of the party which are vulnerable to the activities of a new party based on the hope that other party may perform a specific activity which is significant for the trustee, regardless for the other party capabilities of monitoring and controlling are required party (Akrout, Raies, \& Woodside, 2019). Analysis of the related literature displays varies across the various contexts that construct of the trustee backgrounds (Baeckstrom, Marsh, \& Silvester, 2019; Georgarakos \& Inderst, 2011). The current study is conducted along with the financial advice framework, it takes over-all perspective of the client trust and also contains client trust in namely, "(1) financial adviser, (2) adviser's institution (3) and financial adviser" (Nguyen et al., 2016). Therefore, there was remained a different conceptualizations in the FL which is consistent with the previous studies (Bollen \& Posavac, 2018; Gallery, Newton, \& Palm, 2011; Koh, Mitchell, \& Rohwedder, 2018). Consequently we accept the broadly used definition of the Kojo Oseifuah (2010) and capability to create the informed judgments as well as also take the significant decisions about the management and use of the money.

On the other hand, when one party is trust on the other party, it is similarly that they can acquire and understand helpful information from the other (Evans, Frissen, \& Choo, 2018; Hanson \& Kalthoff, 2018; Levin \& Cross, 2004; Levin, Whitener, \& Cross, 2006). Certainly, previous studies have revealed a positive association among the knowledge transfer and trust at together the individual as well as in different context of firms' level (Stoel \& Muhanna, 2012). Moreover, trust, make sure to consistent evidence that the people are probably to gain additional knowledge from the long-term association (Lee \& Moss, 2018; Mäkelä \& Brewster, 2009; Nguyen, Gallery, \& Newton, 2019). Therefore, it is also hypothesized that the client trusts in service of the financial advice, and association with service that will have significant and positive association with the client FL (H1)

H1: In the financial advice client trust has significant relationship with the client FL of the banking industry of Indonesia

A positive and significant association between the risk tolerance (RT) and trust has been found in the extant previous studies and these studies further recommended that longer-term association to be the trusting tend (Toften \& Hammervoll, 2013). The possible clarification for this association is that the trustor can gain more and better information about trustee, therefore is similarly to further trust them (Alcock \& Andrlikova, 2018; Dyer \& Chu, 2000; Shenkman \& Shenkman, 2019; Udomkit, Ensslin, \& Meinhold, 2019). In line with this, extent of the time that an individual has knowledgeable risks that remain to influence on RT of the organization (Buratti \& Allwood, 2019). Accordingly, based on the previous studies the positive and significant association between RT and financial literacy (FL) has been constantly supported by (Ferreira \& Dickason-Koekemoer, 2019; Gibson et al., 2013; Caplinska, Ohotina, 2019).

As, Beal and Delpachitra (2003) also stated that their study on the FL of the Australian students' and establish that members' who took minimum risk adverse has more skills and financial knowledge. Frijns, Koellen, and Lehnert (2008) and Nguyen et al. (2019) also observed the effects of the self-assessed in financial skills on the choice of portfolio. Based on the previous discussion, the hypothesis (H2) is suggested:

H2: Client FL has significant association with the client RT in the bank sector of Indonesia.

Rahman (2019) and Olsen (2008) was reviewed the literature on the trust and reported the significant result that more trust is associated to lesser risk perception (RP) in the financial market. In the context of financial, Diacon et al. (2004) also found that trust of investor in the financial products towards key measurement of RP of individual investor in the market. In this framework, due to difficult nature in the process of investment the greatest unsophisticated investors comprehensively depend on financial advisors' approvals in making their investment decisions (Bucciol \& Miniaci, 2018; Nguyen et al., 2019; Yazdipour \& Constand, 2010). Consequently, follow- 
ing hypothesized (H3) is suggested that:

H3: The client trust in service of the financial advice has a significant association with the client RP in the banking sector of Indonesia.

In addition, evidence in extant literature recommended that the investors who have a greater knowledge about the financial manufacturing goods or remain higher familiar in the product tend could perceive the less risky product (Nguyen et al., 2019). In the same way, Wang et al. (2011) also explained in their study that Germanspeaking region of the Switzerland which contains on the exceeding 1200 individuals and investor also found that when the individual has a greater knowledge about the RP, then he could be able to take a good investment and assets remained perceived as minimum risky. In this way these findings indicate a negative association between RP and financial literacy as those who have more financial literacy remain more similarly with higher knowledge about products of investment. Hence, the following hypothesized (H4) is that:

H4: The client financial literacy has a significant association with the client RP in the banking sector of Indonesia.

Furthermore, risk-averse people are tending to the overestimate of negative outcomes, most important for them to higher perceive risk although risk- pursuing people remain similarly to overvalue the positive results subsidizing towards a risk in lower perceived of the individual (Schneider \& Lopes, 1986). Sitkin and Weingart (1995), Prietzel (2019) and Martino, Rigolini, and D'Onza (2018) further explained that propensity of risk negatively affected on risk perception (RP). Moreover, in the financial services context, Gibson et al. (2013) was conducted a study over 2000 respondents from the USA as well as it is generally found in individually female and male respondents who were perceived stock in the market towards riskier at the moment matched to the time which is about the GFC remained more similarly to have less scores in risk tolerance (RT). This is supported by the previous research, a person who is opposing to taking an investment great similarly to perceive products of an investment for a risk seeker as caompared to riskier. Therefore, following hypothesized (H5) is that:

H5: Client financial risk tolerance (RT) has significant association with the client RP in the banking industry of Indonesia.

In addition, the research in various disciplines has point out that perception have negative effect on the individual executive (Byrne, 2005; Oehler \& Wedlich, 2018). For instance, Hunter (2002) conducted a study by using aircraft pilots to inspect the perception of pilot risk and also stated an important negative association amongst the perception mark of pilot risk as well as their dangerous movement involvement index which signifying that pilots who were perceive minimum risk remain probably to take a part in the dangerous happenings. Similarly, in the financial context, Byrne (2015) and Bollen and Posavac (2018) also examined the association within the customers' perception of financial risk and asset allocation in many financial products. In addition, Byrne also found a significant correlation between investment decision and perception of financial risk. These findings advice that investors remain less invest in these types of products they were perceive higher risky as well as vice versa. Based on the previous discussions, it is hypothesized (H6) that:

H6: The client RP has a significant association with the asset allocation in the banking industry of Indonesia.

In addition Sitkin and Weingart (1995) also found that risk perception (RP) which is absolutely mediated the association between risky behavior and risk inclination. In addition, their results were representing that people by more risk propensity remain higher likely towards perceive the risky prime to remain of lesser risk, leading to the bigger tendency for them towards acceptance of risky option. On the contrary, individuals who are the risk-averse remain more likely have great RP that is directed them to take minimum risky choices. Furthermore, the study of Sitkin and Pablo (1992) and Sarafan, Squire, and Brandon-Jones (2019) indicates that risk tolerance (RT) (Salem et al., 2018) just not have direct effect on the asset allocation but also it indirectly by 
the RP. Although, Sitkin and Pablo (1992) also found a comprehensive mediation effect of the RP and their study was not prevailing in the context of financial advice (like in our study). In addition, they also studied a connecting but various risk concept: the risk propensity is not a RT. As in the previous literature financial RT originate positively and significantly associated with the decisions of the investment (Cardak \& Wilkins, 2009), the current study was examined the direct association within the asset allocation and RT as well as hypothesize that the financial RP which is mediate in the RT allocation decisions such as follows: Based on the following discussion, research hypothesis is formulated;

H7: Client RT has a significant association with the client RP in the banking industry of Indonesia.

H8: Client RT has a significant association with the asset allocation indirectly through client RP in the banking industry of Indonesia.

\section{Research Framework}

\section{Methodology}

The cross-sectional research design and quantitative research approach was employed in the current study.

The results of quantitative approach method are based on the self-administered questionnaire, it is limited to numbers, statistics, the measurement of data and many forms of statistical analysis. The questionnaire was designed according to the objectives, problem and hypotheses of the study to determine the relative importance of factors that may control the risk factors in the in the banking sector of Indonesia. The data collected through the surveys by distributing among the 300 financial advisers' clients of the banking sector of Indonesia by using convenient sampling technique. The total 210 questionnaires were returned back from managers which yield $70 \%$ response rate. All of the questionnaires were loaded into the Microsoft Excel, the IBM SPSS, and SmartPLS. The five point Likert scale is used to operationalize the variables and their sub constructs.

\section{Measures}

In the current study, five items for the trust has been adopted from the study of (Newton, Corones, Irving, \& Thomas, 2015). In addition, financial literacy was measured by six items which are following "(i) budget day to day finances, (ii) save money, (iii) manage debt, (iv) invest money, (v) plan for the financial future and (vi) save enough money for retirement". All of these items for the financial literacy were adopted from the Mercer Financial Literacy and Retirement Preparedness Survey (2006). In addition, five items for the risk perception was adopted from the stud of. These measured the following factor, "Understanding, Worry and Loss related factor, Regulation, Attention, Trust in Product, Performance Predictability, Gain and Volatility". On the other hand, for the risk tolerance, four items were adopted from the survey study of (Newton et al., 2015; Nguyen et al., 2016). Lastly, for the research allocation six items were adopted from the study of (Nguyen et al., 2016). There are following items which covered the asset allocation "(i) Bank deposit (fixed interest savings), (ii) units in a managed fund which buys shares (unit trust), (iii) bonds/ unsecured notes, (iv) units in a managed fund which buys property (property trust), (v) Australian shares, and (vi) international shares".

\section{Research Analysis and Discussion}

The Partial Leat Square- Structural Equation Modeling technique was employed to analyze the results of the study. Recently, there are many researchers Patidar and Din (2018) and Ahmed, Zin, and Majid (2016) who recommended that when we want to create a novelty in the research model or want to take advancement in the existing phenomena, we should prefer to the SEM analysis The reason why the SEM-PLS is preferred our the multiple regression is that the earlier handles the multiple equations simultaneously and can produces results with a simultaneous operation by producing a relationship with all direct and intervening phenomena. Reliability analysis is performed in order to find internal consistency of the items. Cronbach's alpha is the most 
widely used in order to test the reliability level. Although there are many findings that founds that the value of composite reliability is always higher than Cronbach's alpha. In the current study, to check the indicator factor loading and internal consistency, the minimum value for the factor loading was set 0.5 , for composite reliability 0.7 and for Cronbach's alpha was 0.7 (Hair, Hollingsworth, Randolph, \& Chong, 2017) . Furthermore, Average Variance Extracted (AVE) also examined as one of measure that is useful in establishing validity with the minimum value of 0.5 (Hair et al., 2017). Since by analyzing the convergent validity, it can ensure that the variables correlate well with each other within their parent factor, either mediating or dependent variable. For the discriminant validity, HTMT, cross loadings and Forner Lacker have been discussed in the previous literature (Henseler, Ringle, \& Sarstedt, 2015; Henseler, Ringle, \& Sinkovics, 2009). All the results for the measurement model has been depicted in the following Tables 1,2 and 3.

Table 1. Measurement Model

\begin{tabular}{|c|c|c|c|c|c|}
\hline Constructs & Items & Loadings & Alpha & $\mathbf{C R}$ & AVE \\
\hline \multirow[t]{6}{*}{ Financial Literacy } & FL1 & 0.837 & 0.851 & 0.9 & 0.693 \\
\hline & FL2 & 0.785 & & & \\
\hline & FL3 & 0.879 & & & \\
\hline & FL4 & 0.825 & & & \\
\hline & FL5 & 0.650 & & & \\
\hline & FL6 & 0.740 & & & \\
\hline \multirow[t]{4}{*}{ Risk tolerance } & RT1 & 0.758 & 0.758 & 0.839 & 0.512 \\
\hline & RT2 & 0.702 & & & \\
\hline & RT3 & 0.793 & & & \\
\hline & RT4 & 0.704 & & & \\
\hline \multirow[t]{6}{*}{ Trust } & TRU1 & 0.703 & 0.774 & 0.847 & 0.526 \\
\hline & TRU2 & 0.701 & & & \\
\hline & TRU3 & 0.705 & & & \\
\hline & TRU4 & 0.814 & & & \\
\hline & TRU5 & 0.796 & & & \\
\hline & TRU6 & & & & \\
\hline \multirow[t]{5}{*}{ Risk Perception } & RP1 & 0.795 & 0.834 & 0.798 & 0.654 \\
\hline & RP2 & 0.809 & & & \\
\hline & RP3 & 0.839 & & & \\
\hline & RP4 & 0.768 & & & \\
\hline & RP5 & 0.560 & & & \\
\hline \multirow[t]{6}{*}{ Asset Allocation } & AL1 & 0.806 & 0.876 & 0.80 & 0.645 \\
\hline & AL2 & 0.786 & & & \\
\hline & AL3 & 0.719 & & & \\
\hline & AL4 & 0.657 & & & \\
\hline & AL5 & 0.591 & & & \\
\hline & AL6 & 0.786 & & & \\
\hline
\end{tabular}

Note: FL-Financial Literacy, RT- Risk tolerance, TRU- Trust, RP- Risk Perception, AL-Asset allocation 
Table 2. Fornell and Larcker Criterion for Discriminant Validity

\begin{tabular}{|c|c|c|c|c|c|}
\hline & FL & RT & TRU & RP & $\mathbf{A L}$ \\
\hline FL & 0.755 & & & & \\
\hline RT & 0.436 & 0.722 & & & \\
\hline TRU & 0.522 & 0.437 & 0.736 & & \\
\hline RP & 0.434 & 0.51 & 0.563 & 0.709 & \\
\hline $\mathbf{A L}$ & 0.353 & 0.686 & 0.407 & 0.472 & 0.722 \\
\hline
\end{tabular}

Note: FL-Financial Literacy, RT- Risk tolerance, TRU- Trust, RP- Risk Perception, AL-Asset allocation

Table 3. HTMT Analysis for Discriminant Validity

\begin{tabular}{cccccc}
\hline & FL & RT & TRU & RP & AL \\
\hline FL & & & & & \\
RT & 0.436 & & & & \\
TRU & 0.533 & 0.437 & & & \\
RP & 0.434 & 0.51 & 0.563 & 0.472 & \\
AL & 0.353 & 0.686 & 0.407 & 0.72 & \\
\hline
\end{tabular}

Note: FL-Financial Literacy, RT- Risk tolerance, TRU- Trust, RP- Risk Perception, AL-Asset allocation

\section{Structural Model}

When we assess the measurement model of the study, the next process for the analysis is to test the structural model of the study. For this purpose, the bootstrap resamples 500 techniques by using the 0.05 level of significance and 1.96 t-statistics was employed. The SEM analysis has shown that risk has a positive and significant association with the risk perception and financial literacy. On the other hand, financial literacy has insignificant association with the risk perception, while financial literacy has positive and significant association with the risk tolerance. In addition, the risk tolerance has a positive and significant association with the with asset allocation and while negative with the risk perception. On the other hand, it is also found that risk perception creates a positive and significant in the relationship of risk tolerance and asset allocation in the banking industry of Indonesia. These findings have shown that banking sector of the Malaysia is able to manage the risk. The key findings are consistent with the study of (Feng et al., 2018). The results of these findings are depicted in the following Table 4 and Figure 1.

Table 4. structural model results

\begin{tabular}{|l|c|c|c|c|c|}
\hline & Beta & SD & T Statistics & P Values & Results \\
\hline FINANCIAL LITERACY -> RISK PERCEPTION & 0.054 & 0.061 & 0.88 & 0.379 & rejected \\
\hline FINANCIAL LITERACY -> RISK TOLERANCE & 0.227 & 0.062 & 3.69 & 0.000 & Accepted \\
\hline RISK PERCEPTION -> ASSET ALLOCATION & 0.326 & 0.07 & 4.636 & 0.000 & Accepted \\
\hline RISK TOLERANCE -> ASSET ALLOCATION & 0.514 & 0.068 & 7.584 & 0.000 & Accepted \\
\hline RISK TOLERANCE -> RISK PERCEPTION & -0.836 & 0.02 & 41.83 & 0.000 & Accepted \\
\hline TRUST -> FINANCIAL LITERACY & 0.81 & 0.018 & 44.992 & 0.000 & Accepted \\
\hline TRUST -> RISK PERCEPTION & 0.036 & 0.054 & 0.663 & 0.508 & Accepted \\
\hline $\begin{array}{l}\text { RISK TOLERANCE -> RISK PERCEPTION -> } \\
\text { ASSET ALLOCATION }\end{array}$ & 0.325 & 0.07 & 4.635 & 0.000 & Accepted \\
\hline
\end{tabular}

Note: FL-Financial Literacy, RT- Risk tolerance, TRU- Trust, RP- Risk Perception, AL-Asset allocation 


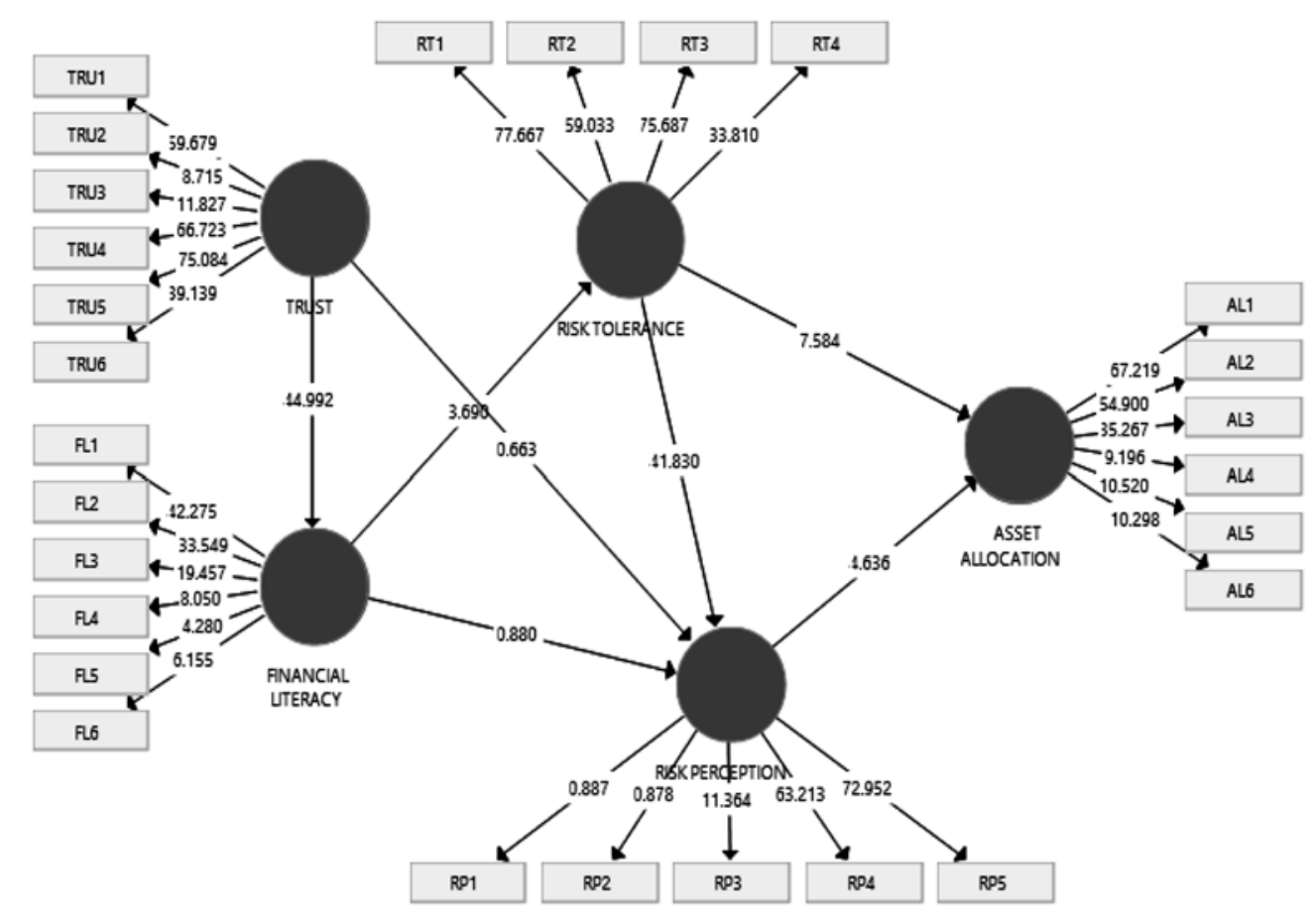

Figure 1. Structural Model of the study

\section{Conclusion}

The aim of the study was being to investigate the join effect of risk tolerance (RT) and risk perception (RP) on the individual risky asset allocation decision along with the other essential variable in the context of financial advice which is consist of financial literacy and trust. The key findings have shown that trust has significant relation with the financial literacy and risk tolerance. In addition, the financial literacy also shown a positive and significant relationship with the RT but has insignificant relation with the RP in the banking sector of Indonesia. In other RP is significantly intervened in the relationship of RT and asset allocation. A possible explanation for this findings is that risk that risk-avoiders tend to "overestimate negative outcomes, thus perceiving more risk, while risk seekers tend to overweigh positive outcomes, therefore perceiving less risk (Schneider and Lopes, 1986; March and Shapira, 1987 as cited in Sitkin and Weingart, 1995)". In addition, key findings have shown that RT and RP have a negative and significant relationship which is supported by the extant literature stream Gibson et al.'s (2013). Moreover, it is found that RT and RP have positive and significant association with the asset allocation. On the other hand, the risk perception also creates a positive and significant association within the risk tolerance and asset allocation. Based on the findings of the study, the current could provide help to the financial advisor to control the risk of the organization. The current study also added a body of literature in the form of empirical findings which could become a new area of research in future. Based on the findings, current study also has several limitations, firstly, current study was limited on the banking sector, therefore, future research could be established on other financial institutions. secondly, the study was cross sectional in nature, hence a future research could be established on the longitudinal research. In addition, to check the variation in the findings, a future could be established along with the moderator in their relationship.

\section{References}

Ahmad, R. (2019). Exploring the Relationship of Intellectual Capital, Board Characteristics and Business Performance: A Literature Review. Pakistan Journal of Humanities and Social Sciences, 7(2), 185-202.

Ahmed, U., Zin, M. L. M., \& Majid, A. H. A. (2016). Impact of Intention and Technology Awareness on Transport Industry's E-service: Evidence from an Emerging Economy. 산경연구논집 (IJIDB), 7(3), 13-18. https://doi.org/10.13106/ijidb.2016.vol7.no3.13 
Approach: Emerald Group Publishing. https://doi.org/10.1108/S1069-0964201926

Alcock, J., \& Andrlikova, P. (2018). Asymmetric Dependence in Real Estate Investment Trusts: An Asset-Pricing Analysis. The Journal of Real Estate Finance and Economics, 56(2), 183-216. https://doi.org/10.1007/s11146-016-9593-9

Angelini, D. E., Radivoyevitch, T., McCrae, K. R., \& Khorana, A. A. (2019). Bleeding incidence and risk factors among cancer patients treated with anticoagulation. American journal of hematology, 94(7), 780-785. https://doi.org/10.1002/ajh.25494

Baeckstrom, Y., Marsh, I. W., \& Silvester, J. (2019). Financial Advice, Wealth and Gender: Risk Tolerance, Knowledge and Confidence. Wealth and Gender: Risk Tolerance, Knowledge and Confidence (May 11, 2019). https://dx.doi.org/10.2139/ssrn.3286336

Dyer, J. H., \& Chu, W. (2000). The determinants of trust in supplier-automaker relationships in the US, Japan and Korea. Journal of International Business Studies, 31(2), 259-285. https://doi.org/10.1057/palgrave.jibs.8490905

Beal, D. J., \& Delpachitra, S. B. (2003). Financial literacy among Australian university students. Economic Papers: A journal of applied economics and policy, 22(1), 65-78. https://doi.org/10.1111/j.1759-3441.2003.tb00337.x

Bollen, N. P., \& Posavac, S. (2018). Gender, risk tolerance, and false consensus in asset allocation recommendations. Journal of banking \& Finance, 87, 304-317. https://doi.org/10.1016/j.jbankfin.2017.10.016

Bucciol, A., \& Miniaci, R. (2018). Financial risk propensity, business cycles and perceived risk exposure. Oxford Bulletin of Economics and Statistics, 80(1), 160-183.

Buratti, S., \& Allwood, C. M. (2019). The effect of knowledge and ignorance assessments on perceived risk. Journal of Risk Research, 22(6), 735-748. https://doi.org/10.1080/13669877.2018.1459795

Byrne, K. (2005). How do consumers evaluate risk in financial products? Journal of Financial Services Marketing, 10(1), 21-36. https:// doi.org/10.1057/palgrave.fsm.4770171

Byrne, K. (2015). How do consumers evaluate risk in financial products? Journal of Financial Services Marketing, 10(1), 21-36. https:// doi.org/10.1057/palgrave.fsm.4770171

Caplinska, A., Ohotina, A. 2019. Analysis of financial literacy tendencies with young people. Entrepreneurship and Sustainability Issues, 6(4), 6(4) 1736-1749. http://doi.org/10.9770/jesi.2019.6.4(13)

Cardak, B. A., \& Wilkins, R. (2009). The determinants of household risky asset holdings: Australian evidence on background risk and other factors. Journal of banking \& Finance, 33(5), 850-860. https://doi.org/10.1016/j.jbankfin.2008.09.021

Costa Jr, P. T., McCrae, R. R., \& Löckenhoff, C. E. (2019). Personality across the life span. Annual Review of Psychology, 70, $423-448$. https://doi.org/10.1146/annurev-psych-010418-103244

de Goeij, P., Van Campenhout, G., \& Subotic, M. (2018). Improving index mutual fund risk perception: Increase financial literacy or communicate better?(Published Online). https://doi.org/10.1111/ecno.12112

Diacon, A. H., Theron, J., Schuurmans, M. M., Van de Wal, B. W., \& Bolliger, C. T. (2004). Intrapleural streptokinase for empyema and complicated parapneumonic effusions. American journal of respiratory and critical care medicine, 170(1), 49-53". https://doi. org/10.1164/rccm.200312-1740OC

Erdemlioglu, D., \& Joliet, R. (2019). Long-term asset allocation, risk tolerance and market sentiment. Journal of International Financial Markets, Institutions and Money. https://doi.org/10.1016/j.intfin.2019.04.004

Evans, M., Frissen, I., \& Choo, C. W. (2018). Examining the Mediating Effect of Co-Worker.. Trust.. etween........ Strength and Effective Organizational Knowledge Sharing. Paper presented at the European Conference on Knowledge Management.

Feng, M., Yu, W., Wang, X., Wong, C. Y., Xu, M., \& Xiao, Z. (2018). Green supply chain management and financial performance: The mediating roles of operational and environmental performance. Business strategy and the Environment, 27(7), 811-824. https://doi. org/10.1002/bse. 2033

Ferreira, S., \& Dickason-Koekemoer, Z. (2019). The Relationship Between Depositor Behaviour and Risk Tolerance in a South African Context. Advances in Decision Sciences, 23(3), 1-19.

Frijns, B., Koellen, E., \& Lehnert, T. (2008). On the determinants of portfolio choice. Journal of Economic Behavior \& Organization, 66(2), 373-386. https://doi.org/10.1016/j.jebo.2006.04.004

Gallery, N., Newton, C., \& Palm, C. (2011). Framework for assessing financial literacy and superannuation investment choice decisions. 
Australasian Accounting, Business and Finance Journal, 5(2), 3-22.

Georgarakos, D., \& Inderst, R. (2011). Financial advice and stock market participation. European Central Bank.

Gibson, R., Michayluk, D., \& Van de Venter, G. (2013). Financial risk tolerance: An analysis of unexplored factors. Financial Services Review.

Grable, J. (2008). Risk Tolerance (pp. 1-20). Advances in Consumer Financial Behavior Research. New York: Springer.

Hair, Hollingsworth, C. L., Randolph, A. B., \& Chong, A. Y. L. (2017). An updated and expanded assessment of PLS-SEM in information systems research. Industrial Management \& Data Systems, 117(3), 442-458. https://doi.org/10.1108/IMDS-04-2016-0130

Hanson, T., \& Kalthoff, J. (2018). Financial literacy, naïve diversification, and security selection. Journal of Applied Financial Research, $1,69-86$.

Henseler, J., Ringle, C. M., \& Sarstedt, M. (2015). A new criterion for assessing discriminant validity in variance-based structural equation modeling. Journal of the academy of marketing science, 43(1), 115-135. https://doi.org/10.1007/s11747-014-0403-8

Henseler, J., Ringle, C. M., \& Sinkovics, R. R. (2009). The use of partial least squares path modeling in international marketing. In New challenges to international marketing (pp. 277-319): Emerald Group Publishing Limited. https://oi.org/10.1108/S14747979(2009)0000020014

Huber, J., Palan, S., \& Zeisberger, S. (2019). Does investor risk perception drive asset prices in markets? Experimental evidence. Journal of banking \& Finance, 108, 105635. https://doi.org/10.1016/j.jbankfin.2019.105635

Hunter, D. R. (2002). Risk perception and risk tolerance in aircraft pilots.

Koh, B. S., Mitchell, O. S., \& Rohwedder, S. (2018). Financial knowledge and portfolio complexity in Singapore. The Journal of the Economics of Ageing, 100179. https://doi.org/10.1016/j.jeoa.2018.11.004

Kojo Oseifuah, E. (2010). Financial literacy and youth entrepreneurship in South Africa. African journal of Economic and management studies, 1(2), 164-182.

Koonce, L., McAnally, M. L., \& Mercer, M. (2015). How do investors judge the risk of financial items? The accounting review, 80(1), 221-241. https://doi.org/10.2308/accr.2005.80.1.221

Lee, S., \& Moss, A. (2018). REIT asset allocation. In The Routledge REITs Research Handbook (pp. 139-152): Routledge.

Levin, D. Z., \& Cross, R. (2004). The strength of weak ties you can trust: The mediating role of trust in effective knowledge transfer. Management science, 50(11), 1477-1490. https://doi.org/10.1287/mnsc.1030.0136

Levin, D. Z., Whitener, E. M., \& Cross, R. (2006). Perceived trustworthiness of knowledge sources: The moderating impact of relationship length. Journal of applied psychology, 91(5), 1163. https://doi.org/10.1037/0021-9010.91.5.1163

Mäkelä, K., \& Brewster, C. (2009). Interunit interaction contexts, interpersonal social capital, and the differing levels of knowledge sharing. Human Resource Management: Published in Cooperation" "with the School of Business Administration, The University of Michigan and in alliance with the Society of Human Resources Management, 48(4), 591-613. https://doi.org/10.1002/hrm.20300

Martino, P., Rigolini, A., \& D'Onza, G. (2018). The relationships between CEO characteristics and strategic risk-taking in family firms. Journal of Risk Research, 1-22. https://doi.org/10.1080/13669877.2018.1517380

McCarthy, J. E., \& Levin, D. Z. (2019). Network residues: The enduring impact of intra-organizational dormant ties. Journal of applied psychology. https://psycnet.apa.org/doi/10.1037/ap10000410

Mellers, B. A., \& Chang, S. (1994). Representations of risk judgments. Organizational behavior and human decision processes, 57, 167-167.

Nasr, A.K., Alaei, S., Bakhshi, F., Rasoulyan, F., Tayaran, H., Farahi, M. 2019. How enterprise risk management (erm) can affect on short-term and long-term firm performance: evidence from the Iranian banking system. Entrepreneurship and Sustainability Issues, 7(2), 1387-1403. http://doi.org/10.9770/jesi.2019.7.2(41)

Newton, C., Corones, S., Irving, K., \& Thomas, D. (2015). The Value of Financial Planning Advice: Process and Outcome Effects on Consumer Well-being [Time 1 and 2 Survey Summary Results].

Nguyen, L., Gallery, G., \& Newton, C. (2016). The influence of financial risk tolerance on investment decision-making in a financial 
advice context. Australasian Accounting, Business and Finance Journal, 10(3), 3-22. http://dx.doi.org/10.14453/aabfj.v10i3.2

Nguyen, L., Gallery, G., \& Newton, C. (2019). The joint influence of financial risk perception and risk tolerance on individual investment decision-making. Accounting \& Finance, 59, 747-771. https://doi.org/10.1111/acfi.12295

Oehler, A., \& Wedlich, F. (2018). The relationship of extraversion and neuroticism with risk attitude, risk perception, and return expectations. Journal of Neuroscience, Psychology, and Economics, 11(2), 63. https://psycnet.apa.org/doi/10.1037/npe0000088

Olsen, R. A. (2008). Trust as risk and the foundation of investment value. The Journal of Socio-Economics, 37(6), 2189-2200. https:// doi.org/10.1016/j.socec.2008.04.009

Patidar, R., \& Din, T. M. U. (2018). A Study on the Fluctuating Trend of Export (Demand Change) of 'Garlic of India'by its Price Transformation in International Markets, Under the Time Period of 1991 to 2011. International Journal of Applied Economics, Finance and Accounting, 2(2), 54-59. https://doi.org/10.33094/8.2017.2018.22.54.59

Prietzel, T. T. (2019). The effect of emotion on risky decision making in the context of prospect theory: a comprehensive literature review. Management Review Quarterly, 1-41. https://doi.org/10.1007/s11301-019-00169-2

Rahman, M. (2019). Propensity toward financial risk tolerance: an analysis using behavioural factors. Review of Behavioral Finance. https://doi.org/10.1108/RBF-01-2019-0002

Sachse, K., Jungermann, H., \& Belting, J. M. (2012). Investment risk-The perspective of individual investors. Journal of Economic Psychology, 33(3), 437-447. https://doi.org/10.1016/j.joep.2011.12.006

Salem, M., Shawtari, F., Shamsudin, M. \& Hussain, H. I. (2018) The Consequences of Integrating Stakeholders' Engagement on Sustainable Development (Environmental Perspectives), Sustainable Development, 26 (3), 255 - 268

Sarafan, M., Squire, B., \& Brandon-Jones, E. (2019). A Behavioural View of Supply Chain Risk Management. In Revisiting Supply Chain Risk (pp. 233-247): Springer. https://doi.org/10.1007/978-3-030-03813-7_14

Schneider, S. L., \& Lopes, L. L. (1986). Reflection in preferences under risk: Who and when may suggest why. Journal of Experimental Psychology: Human perception and performance, 12(4), 535. https://psycnet.apa.org/doi/10.1037/0096-1523.12.4.535

Shenkman, J. I., \& Shenkman, M. M. (2019). Tax, Estate Planning, and Asset Protection Considerations. The CPA Journal, 89(7), 69-71.

Sitkin, S. B., \& Pablo, A. L. (1992). Reconceptualizing the determinants of risk behavior. Academy of management review, 17(1), 9-38. https://psycnet.apa.org/doi/10.2307/258646

Sitkin, S. B., \& Weingart, L. R. (1995). Determinants of risky decision-making behavior: A test of the mediating role of risk perceptions and propensity. Academy of Management Journal, 38(6), 1573-1592. https://doi.org/10.5465/256844

Stoel, M. D., \& Muhanna, W. A. (2012). The dimensions and directionality of trust and their roles in the development of shared business-IS understanding. Information \& management, 49(5), 248-256. https://doi.org/10.1016/j.im.2012.06.001

Toften, K., \& Hammervoll, T. (2013). Niche marketing research: status and challenges. Marketing Intelligence \& Planning, 31(3), 272-285. https://doi.org/10.1108/02634501311324618

Tsai, F.-S., \& Hsu, I.-C. (2019). The effects of social capital on knowledge heterogeneity. Management decision, 57(5), $1237-1253$. https://doi.org/10.1108/MD-12-2016-0909

Tsai, W. (2000). Social capital, strategic relatedness and the formation of intraorganizational linkages. Strategic management journal, 21(9), 925-939. https://doi.org/10.1002/1097-0266(200009)21:9\%3C925::AID-SMJ129\%3E3.0.CO;2-I

Udomkit, N., Ensslin, V., \& Meinhold, R. (2019). Three Stages of Trust Building of International Small-and Medium-Sized Enterprises. Global Business Review, 0972150919856990”. https://doi.org/10.1177/0972150919856990

Wang, M., Keller, C., \& Siegrist, M. (2011). The less You know, the more You are afraid of-A survey on risk perceptions of investment products. Journal of Behavioral Finance, 12(1), 9-19. https://doi.org/10.1080/15427560.2011.548760

Yazdipour, R., \& Constand, R. (2010). Predicting firm failure: A behavioral finance perspective. The Journal of Entrepreneurial Finance, 14(3), 90-104.

Yin, H., Chen, Z., \& Xiao, Y. (2019). Risk perception affecting the performance of shipping companies: the moderating effect of China and Korea. Maritime Policy \& Management, 46(3), 295-308. https://doi.org/10.1080/03088839.2018.1540890 
Natnaporn AEKNARAJINDAWAT is a lecturer of Doctor of Philosophy Program in Development Administration, Suan Sunandha Rajabhat University, Thailand. Her research areas are Public and Private Administration, Development Administration, and Leadership.

This work is licensed under the Creative Commons Attribution International License (CC BY). http://creativecommons.org/licenses/by/4.0/ 